$\underline{\xi=1}$

\title{
Climate change, food security and environmental security : A conflict inclination assessment of Karamoja region of Uganda
}

\author{
Oluwole O. Akiyode ${ }^{1}$, Anne Tumushabe ${ }^{1}$, Katongole Hadijjah ${ }^{1}$; Onu Peter ${ }^{2}$ \\ ${ }^{1}$ Department of Biological and Environmental Science \\ ${ }^{2}$ Department of Mechanical Engineering Kampala International University, Kampala, Uganda \\ *Corresponding author E-mail: oluwole.akiyode@kiu.ac.ug
}

\begin{abstract}
The study investigates the consequences of climate change on food security and environmental security in the Karamoja region of Uganda. It relates climate change to the conflict, insecurity and crises that have been witnessed in the region in the past years.

It examines the implications of the change in the grazing pattern of the pastoralists and herdsmen in the time of recurrent drought and dry spells in Karamoja on the security of the region and other communities in Uganda and beyond. It relates the interplay of climate change, environmental security and food security to human security in Karamoja region.

It also through focus group discussion (FGD) conducted in Kaabong District of the Karamoja region, identifies the presumed impacts of climate change on the environment and the people alongside its socio-economic implications. In the end, the study suggests proactive environmental security programmes in the Karamoja region which are expected to encourage sustainable mitigation and adaptation strategies in its communities, which will encourage its regional peace, security and stability.
\end{abstract}

Keywords: Climate Change; Environmental Security; Food Security; Karamoja; and Conflict.

\section{Introduction}

Climate change is currently a global key phenomenon that is assumable becoming a concern to every part of the world because of its expected implications for human development, society stability and security. It is branded a threat multiplier whose implications on the environment and food security are a perceptible reality.

The degradation of the environmental resources through the influence of climate change is adduced to changes in physicochemical and environmental factors in the affected areas. Such parameters include an increase in temperatures, precipitation anomalies, and extreme weather that are occurring in different areas [1]. Literature at many times also identifies climate change as one of the processes that could encourage resource scarcity, since its effects of the society are sometimes linked to properties that degrade environmental resources, which may adversely impact upon the environment and food security. Thus, these negative impacts on the society goods and essential needs have been suggested to instigate insecurity, conflicts or crises.

The threats and presumed implications of climate change and climate variations have been alleged to have direct effects on agrarian communities in most of the countries in Sub-Saharan Africa, including Uganda. Karamoja region of Uganda has been renowned and purported to be negatively impacted by climate change and climate variations, which have been considered the basis for its recurrent drought, dry spells and famine. Nevertheless, the understanding of the implications of climate change and its variations and the working of sustainable adaptation strategies in the region may be fundamental to the sustenance of sustainable development in the region [2].
Climate change and its variations could be classified as one of the determinants of the environmental security of every agrarian community in the recent years in different parts of the world, especially when considering its adverse implications on the environment. Subsequently, climate change and its variation may define the levels of food security, agricultural production and most importantly the societal well-being.

Moreover, some researchers in their articles since the 1980s suggest that the threats and effects of climate change and climate variations might be sometimes potential conflicts in the effects' food insecurity and environmental crises in any agrarian community, specifically when there might have been scarcities of dependable resources that determined agricultural production thereby supporting human livelihood [3].

On this basis, this study aligns with the conceptual framework of Baechler (1998) in his research article titled "Why Environmental Transformation Causes Violence: A synthesis" that environmental change can either be a contributory or a factor that is necessary to both the emergence and /or the intensification of the violent conflict [4]. Consequently, this study examines the interplay of the potential of climate change in distorting the food security and environmental security of the Karamoja region of Uganda as a case in analyzing its effects on the human and socio-economic development as well as its contribution to the recurring conflicts that have been witnessed in the region.

\section{Methodology}

The study reviews the literature on climate change, food security and environmental security of Karamoja region in Uganda in order 
to assess the consequences of climate change on human and societal developments. It also investigates and analyses the interplay of climate change on the environment through focus group discussion (FGD) conducted on Karamojo residents using Kaabong District in Karamoja region, Uganda as a case.

\section{Environmental security, food security and conflict}

Peace and security are essential for the sustenance of life, economy and societal developments. Development is associated with security, to the extent that there may not be development without security and no security without development [5] [6] [7]. However, the word "security" has undergone revisions by scholars and policymakers making it grow bigger day by day than the already familiar traditional security. This makes its definitions to drift from its traditional scope to some newer scope, which must at times come with modern outlooks.

The newer viewpoint necessitates the attachment of recent appendages by the world policy leaders thereby bringing about broader, more focused and explicit classifications that make it accommodate the protection of our society from physical or external aggression, which encompasses threats from societal needs that sometimes generates tension within the society [8]. Thus, the thought of redefining of security and what constitutes national security may be essential for the current-day [9].

One of the newer or recent appendages attached to security in the recent time is Environmental Security. This security embeds the society with its ecology. It demonstrates that there is an inherent link between environment and security. Environmental security is cogent to food security. Since food and agricultural production can only thrive in a pristine and unspoiled environment. Environmental security is the implications of environmental degradation, stress and scarcity due to migration, disasters, conflict, and crises and on the resolution, prevention and avoidance of environmental damage [10]. Therefore, environmental security includes energy security and climate security to water and health security [11]. All these functional parameters are indispensable in stabilizing food security. However, a viable environmental security will minimize environmental damage and promotes sustainable development [12]. Kreimer (2003) definition of environmental security and Pachauri (2000) submission on the same subject supports the argument of Soroos (1994) that environmental security will prevent or minimize human-induced changes to the environment which will degrade, disrupt and may avert adverse consequences for current and future generations[10] [12] [13]. This makes environmental security a linkage between the environment, natural resources and conflict [14].

The issue of the environment such as food security which may threaten national security is included in the environmental security paradigm [15]. This makes the concerns of climate change and global change, which may hinder food security to be under watched in every society since scholars since around 1990's links environmental change to conflict. Aforetime, the environment-conflict nexus has been the object of debate for sometime now, and resource scarcity has been promulgated to contribute to violence conflict [16] [17].

Also, the former United Nations Secretary-General Ban ki-Moon on March 1, 2007, toe the line the line of the discussion on the nexus of environment-conflict by emphasizing that the connection of the global climate change, and its contribution to conflict is prime to the United Nations work [18]. He reiterated further that the focus was on preventing and ending conflict when the danger posed by war to all the humanity, and to our planet is at least matched by the climate crisis and global warming in which the effects of climate change may likely become a major driver of war and conflict. This notion invariably supports the eco-violence postulation.

\section{Uganda agrarian communities and the pas- toralists}

In Uganda, the last decades have been characterized by a change in herdsmen and pastoral migration. This has been associated with environmental harsh conditions such as drought, flash floods and dry spells which limit the availability of pastures for herds in mostly the northeastern parts of the country. Thereby, making the pastoralists or herdsmen in this region of Uganda to sometimes need to move at most times westwards and southward of the country for pastures and water for their herds. This aligns with the assertion that "[m]igration can occur either because the environmental quality of a habitat that has become unlivable (push factor) or more commonly because the migrants' economy is likely to be better in areas with resource availability" (pull factor) [19].

However, this push and pull factors may be assumed as the characters being exhibited by the Karamoja communities residing in the Northern Eastern Uganda in response to drought, flash floods, dry spells and other negative environmental conditions that are being identified as implications of climate change and climate variations by policymakers, the government, and scientists. Thereby, the push and pull factors might have encouraged the movements of the herdsmen and pastoralists in the Karamoja region into other communities within the region and outside it for their cattle and animals food security.

These movements are always inter-ethnic movements or within ethnic movements and also inter-community movements or within and outside community movements. These movements encourage the interferences between the Karamoja herdsmen or pastoralists and their inter-regional communities' agrarian society and other communities' (outside the region) agrarian societies.

Though, historically the Karamoja has always been involved in conflict and crisis in the pre-independence period as parts of their pastoralism adventure but this has continued in post-independence days with recurrent clashes or conflict between the local farmers within and outside the region which might have been aggravated by the regular droughts, flash floods and dry spells being witnessed in the region. These conflicts at different times have claimed human lives and properties. The crises mostly ensue when one ethnic prevents the other from its resources. This is the intrusion of the Karamoja herdsmen or nomadic pastoralists' cattle to graze on the farmland and farm produce of other communities outside or within Karamoja (this movement of herds is done in order to have pastures and water for their animals, mostly during dry seasons that go along with droughts). The Karamoja herdsman or pastoralist practices could be seen as a traditional transhumance whereby they move their herds or livestock from one place to another for pasture in mostly seasonal cycle and still keep home.

The conflict was always becoming dangerous and fatal since most of the herders acquired local and sometimes sophisticated guns to protect their herds from raiders when going for grazing within and outside Karamoja and sometimes needed to utilize the weapons to forcefully have access to grazing sites. This dispute continued unabated before the government initiated forceful disarmament and designed a controlled systematic and regulated usage of guns in the region. Most of the guns in this region were purchased or acquired from the war-torn countries that surround Uganda. Though there has been steadily growing stability in Karamoja region for a while, its recurrent drought and other negative environmental condition's tendencies, which are averse to tending of herds and cattle to the region may still potentiate conflict.

Hence, the crisis or conflict in Karamoja may be regarded as a recurrent natural resource conflict that may sometimes be taken for the inter-ethnic, socioeconomic, socio-political, state and territorial crisis. The inclination aligns with the statement that environmental conflict is expected to manifest as political, economic, social, ethnic, religious and sometimes territorial conflict, or resource conflict and any other type of conflict [20]. It also agrees with the thought of the advocates of resource conflict theory (Toronto Group of researchers on environmental scarcity and violent conflict) which 
advocate that nations or people will fight each other to secure access to the resources that are essential to their survival: the more scarce the resource, the more bitter the fight [20] [21] [22].

\section{The Karamoja region of Uganda}

Karamoja region is located in the Northern Eastern part of Uganda bordered by South Sudan to the north, Kenya to the east and by the districts of Pader, Kitgum, Agago/Lira, Katakwi and Amuria to the West and to the south by Kumi, Sironko, and Kapchorwa. It is made up of seven districts which are Kaabong, Kotido, Moroto, Abim, Amudat, Napak, and Nakapiripirit. Karamoja is now one of the world's poorest areas with eighty-two percent of the 1.3 million inhabitants living in absolute poverty and also have high rates of hunger and malnutrition with estimates suggesting about 100 children with aged less than five die each week from preventable diseases [23]. Also, about 10 to 20 children in Karamoja joins the street per month [24]. The poverty index of the Karamoja region is low as compared to other parts of Uganda. Hence, there has been regular migrations of people because of their low levels of socioeconomic conditions to other parts of Uganda for survival and livelihood.

Historically, the Karamoja people in the central and eastern parts of its region focuses on livestock rearing taking crop production as a subsidiary role as a means of adaptation to the unfavourable climatic condition [25]. The livestock herding or pastoralism are done with its neighbouring districts and regions and remains the main economic base of the people in the region. Crop production in the region is mainly subsistence. The main grown crops in the region are maize and sorghum while other crops include sweet potatoes, cassava, groundnut, vegetables, and beans. Apart from herding or pastoralism and subsistence farming, some mining activities take place in the region.

Recurrent droughts have been a major phenomenon in most parts within the region. Its intensity grows towards the central and North Eastern parts within the region. This affects the socio-economic activities of the entire region. The droughts could be looked at as cyclic since they sometimes occur every two to three years, and the rainfalls are normally episodic alternating through prolonged severe dry seasons with considerable variation from year to year [23].The droughts have always been devastating effects on water supply, crop production, and rearing of livestock which most times lead to famine, malnutrition, epidemics and large population's displacement from one area to another [26]. Thereby, making the region a fragile state that will always need special attention by the government and international aids organizations.

Nevertheless, with the culture and tradition of pastoralism in a region of recurrent droughts and dry spells, the pastorals sometimes will always need to move to different parts of the region from time to time and sometimes to outside its region when droughts are prolonged in order to get pastures for the survival of their cattle, which is the main source of their personal economic security.

\section{Food security and human security in the Karamoja in Uganda}

Recurrent droughts coupled with erratic rainfall, splash flood and prolonged dry spells adduced to climate change and climate variations are attributes of Karamoja region that have made it an area associated with a growing and increasing food insecurity accompanied with untold effects on its people well-being and livelihoods Thus, this unavoidable conditions always has implications on food availability and access in the region, thereby negatively impacting the human security of the region.

For example, the current overview in the year 2016/2017 shows that most parts of Uganda experiences two raining seasons in a year except the Karamoja region with only one raining season that begins from April to September with erratic condition and prolonged dry spells in May/June thereby negatively impacting on the regions' crop development [27]. Agriculture in Karamoja region and other parts of Uganda is mostly rain fed and subsistence.

It was found in 2016 assessment conducted by World Food Program in conjunction with United Nations Children's Fund (UNICEF) and support of the Government of Uganda that $50 \%$ of the population in Karamoja is food insecure while about $12 \%$ were severely food insecure, which may be due to unreliable weather conditions, especially rainfall variations resulting in poor harvest for about three consecutive seasons [28]. Though Global Acute Malnutrition (GAM) was prevalent in the seven districts where the survey was carried out at serious levels in five of the seven districts (Maroto, Kotido, Napak, Kaabong, Nakapirinpint, Abim and Amudat) [28]. The summary of the major underlying factors to food Security in Karamoja Region is poverty-low income levels, low purchasing power, poor food consumption habits, poor sanitation and diseases associated with human, livestock, and crops [29].Food insecurity has negatively impacted the societal development and human development in the region. The education of the children in Karamoja region is already a challenge because of food insecurity, which made the World Food Programme (WFP) since 2015 strategically providing two meals a day per child to cushion food crisis and encourage primary school attendance [30].

There has been a connection between food security and human security in Karamoja region. This is because, unfavourable environmental conditions such as drought, flash floods and dry spells being witnessed in Karamoja region is having direct implications on food security which also has override effects on every aspect of the human security of the region.

Human security takes a view of all threats to human dignity and survival and emphasizes the need to respond to the threats [31]. It is also the security of the people with consideration to their physical safety, social well-being and economy, respect for their dignity and worth, and also the protection of their human right and freedom [32]. Insecurity mightarise from worries about the lack or insufficient food, jobs, and safety [31].

Most of the highlighted attributes of human security have been affected for some time now in Karamoja. Although, there has been continuous improvement in some of the human security components in the recent years. Human dignity and social well-being for most of the residents have been reduced to the lowest ebb. However, the communities in Karamoja are far getting out of personal insecurity (i.e., conditions of not being safe from harm or danger) that was the order of the day for close to twenty years because of the sustained disarmament in the region by the government of Uganda.

\section{Observations/ key findings of the focus group discussions (FGD) and in-depth inter- views conducted in Kathile sub-county Kar- amoja}

From the Focus Group discussions (FDG) and in depth interviews conducted in Kathile Sub County Kaabong District in the Karamoja region on stakeholders (herdsmen, young women, governmental workers, elites and non-elites residents/natives etc.) between third and twenty-fifth of July 2017, the following are deduced from the discussions and the interviews.

The majority of the participants in the FDG accepted that the climate has been changing and asserted that drought is the main impacts of climate change that have affected the Karamoja region. The participants mentioned the following as the effects of climate change in the region.

- Erratic rainfall

- Drought

- Flash flood

- Dry spells

- Malnutrition caused by undernourishment

- Increased crop damage

- Increased poverty 
- Water scarcity and water insecurity

- Increased land degradation

- Loss of biodiversity

- $\quad$ Spread of diseases / epidemics (animals)

- Raised food prices since there has been limited food production because of climate change interferences.

\section{Conclusion}

The study supports the laudable programs of the Republic of Uganda in the quest for total disarmament of the region in order to allow peace and tranquility that will encourage internal and national security thereby supporting socioeconomic development. The study identifies that continuous stability in the region which in the aftermath of the disarmament program of the government of Uganda has elevated business activities in the region thereby encouraging economic growth and livelihood.

However, in order to forestall another crisis that may be imminent in the Karamoja region, there will be needed to swiftly reduce the state of its impoverishment which has impacted negatively on the majority of its people. This will necessitate that governmental presence in terms of enhanced infra structural development such as roads, education, water supplied facilities, health facilities and telecommunication, etc. that are prime for sustainable human security, livelihood security, and region's socio-economy sustainability are expected to be improved.

Likewise, children developmental process which include adequate school education and enrolment is obligatory for the region. Some children are out of school in different parts of Karamoja because of food insecurity and poverty. This is affecting school's enrolment in the region. Thereby, there is needed for the Government of Uganda to essentially address the staying out of school syndrome, which leads to increasing number of street children throughout the country. The school feeding of two meals per day that has been engaged by World Food Programme in some of the school in Karamoja could be adapted for all the schools throughout the region by the government of Uganda. This will lessen society and parent's burden thereby alleviating poverty and less stress.

There should also be processed of relaying information concerning the adaptation and mitigation strategies of climate change to the people of Karamoja. This is because, adequate information, education, and communication of laudable adaptation and mitigation practices encouraged sustainable environmental practices by the citizenry.

\section{References}

[1] C. Raleigh and H. Urdal. Climate Change, Demography, Environmental Degradation, and Armed Conflict. Environment and Security Program, 2009. Available online: https://www.wilsoncenter.org/sites/default/files/ECSPReport13_RaleighUrdal.pdf.

[2] FAO Work on Climate Change. United Nations Conference 2016. Food Agriculture and Organization of the United Nations, 2016. Available online:http://www.fao.org/3/a-i6273e.pdf.

[3] B. Daley. Resource scarcity and environment: Review of evidence and research gap analysis. Evidence on Demand, UK (2013) 26 pp. https://doi.org/10.12774/eod_hd062.jul2013.daley.

[4] G. Baechler. Why Environmental Transformation Causes Violence: A synthesis. "Environmental Change and Security Project Report". Washington DC: The Woodrow Wilson Center Issue 4, Spring 1998, 24-44. Available online: https://www.wilsoncenter.org/sites/default/files/ACF1497.pdf.

[5] N. Tschirgi. The Security-Development Nexus: From Rhetoric to Complex Causal Dynamics in the Swiss Yearbook of Development Policy Vol2/06 (Fall 2006).

[6] R. L. Sexton. Exploring Economics. Seventh Edition. South-Western. Cengage Learning, 2016 (Published January, 2015).

[7] D. Aguirre. The Human Right to Development in a Globalized World. Routledge, 2008.

[8] O.O. Akiyode. Implications of Urbanization on Environmental Security in Developing Economy Countries: A Case Study of Nige-
ria.Journal of Sustainable Development in Africa. 15(3) 2013. Available online: http://www.jsd-africa.com/Jsda/Vol15No3-Summer2013A/PDF/IMPLICATIONS\%20OF\%20URBANIZA-

TION\%20ON\%20ENVIRONMENTAL\%20SECU-

RITY.Oluwole\%20Olusegun\%20Akiyode.pdf.

[9] J. T. Mathews. Redefining Security. Foreign Affairs, spring 1989, 68 , 2, ABI/INFORM Global, 1989 162-177.Available online: https://www.jstor.org/stable/pdf/20043906.pdf?refreqid=excelsior\%3A736561651d402023b9a6ab407654d3d4.

[10] Kreimer A., Arnold M. \& Carlin A. 2003. "Building Safer Cities. The future of Disaster Risk". The World Bank Disaster Project Management facility. Washington DC. Available online: http://documents.worldbank.org/curated/en/584631468779951316/pdf/272110PAPER0Building0safer0cities.pdf.

[11] A. Steiner 2006. Environmental Security". G8 Summit issues and instruments. Available online: http://www.unep.org/org/pdf/environmental_security_pdf.

[12] R. Pachauri and R.E. Benedick. "Environmental Security. A developing Country Perspective". Meeting report of Wilson Center, Environmental Change and Security Project, Current Events, OCT 17, 2000 Available online: http://www.teriin.org/upfiles/pub/articles/art256.pdf.

[13] M. Soroos. Global Change, Environmental Security, and the Prisoner's Dilemma. Journal of Peace Research 1994 31(3):317-332. Available online: https://imedea.uib-csic.es/master/cambioglobal/Modulo_III_cod101608/Additional\%20reading/Soroos $\% 201994 \% 20$ Global\%20change\%20nvironmental\%20security\%20and.pdf. https://doi.org/10.1177/0022343394031003006.

[14] UNEP. United Nations Environmental Development Programme2009).

[15] O. Fagboun. Environmental Degradation and Nigeria's National Security: Making Connections. Law and Security in Nigeria. Nigeria Institute of Advance Legal Studies, 2011 358-383. Available online: http://nials-nigeria.org/pub/OlanrewajuFagbohun.pdf.

[16] T. F. Homer-Dixon, 'Across the Threshold: Empirical Evidence on Environmental Scarcities as Causes of Violent Conflict,'International Security, 1994, 19(1): 5-40. https://doi.org/10.2307/2539147.

[17] T. F. Homer-Dixon. Environment, Scarcity and Violence. Princeton, NJ: Princeton University Press. International Development Research Centre, Ottawa, Canada, 1999.

[18] Canada Free Press. Ban Ki-moon calls on new generation to take better care of Planet Earth than his own, 2007. Available online: http://canadafreepress.com/2007/global-warming030607a.htm.

[19] N.P. Gleditsch and H. Urdal. Ecoviolence? Links between Population Growth, Environmental Scarcity and Violent Conflict in Thomas Homer-Dixon Work. Journal of International Affairs. Fall 2002; 56, $1 /$.

[20] K. Sanjeev and A.Saleem, Environment and Security, Annual Review of Environment and Resources, 2006 31:395-41Annu. Rev. Environ. Resour. 2006. 31:14.1-14.17 doi: 10.1146/annurev.energy.31.042605.134901Available online:http://www.uvm.edu/ shali/KhagramAli.pdf.

[21] E. Page. What's the Point of Environmental Security? Paper for the SGIR 7th Pan-European International Relations Conference Stockholm, 9-11 September 2010 Panel SA-61 Saturday 10 September, 2010. Available online: http://www.eisa-net.org/bebruga/eisa/files/events/stockholm/PageStockholmSGIR2010.pdf.

[22] P. Le Billion. The political ecology of war: natural resources and armed conflicts. Political Geography, $200120 \quad 561-584$. https://doi.org/10.1016/S0962-6298(01)00015-4.

[23] USAID. Climate Risk Screening for Food Security, Karamoja Region, Uganda. USAID, 2017.Available online: https://www.usaid.gov/sites/default/files/documents/1866/170130_Karamoja_Food_Security_Climate_Screening.pdf.

[24] ANPPCAN-Uganda. Annual Situation Reports of Karamojong Children and Families' Street Migration in Uganda. African Network for the Prevention and Protection against Child Abuse and Neglect, 2015 Available online: http://www.anppcanug.org/wp- content/uploads/situation_analysis/sit_analysis_2015.pdf.

[25] Food Agriculture Organization (FAO). Food Security and Agricultural Livelihoods Cluster: Plan Action for Northern Uganda 20082009. Ministry of Agriculture, Animal Industry and Fisheries (MAAIF). FAO, 2009. Available online: https://reliefweb.int/sites/reliefweb.int/files/resources/5411ECE9ED6E055E492575410010BA4D-Full_Report.pdf.

[26] O. Rojas, A. Vrieling and F. Rembold. Assessing drought probability for agricultural areas in Africa with coarse resolution remote sensing 
imagery. Remote Sensing of Environment 115 Elsevier, 2011343 352

[27] FEW NET. Uganda Food Security Outlook October 2016 to May 2017. Famine Early Warning System Network, 2017. Available online:https://reliefweb.int/sites/reliefweb.int/files/re-

sources/Uganda_OL_10_2016_0.pdf.

[28] WFP. Food Security \& Nutrition Assessment Karamoja, Uganda. Analysis conducted by the Analysis, Monitoring and Evaluation Unit, World Food Programme (WFP), Uganda. 2016. Available online: http://documents.wfp.org/stellent/groups/public/documents/ena/wfp286262.pdf?iframe.

[29] IPC. Report of the Integrated Food Security Phase Classification Analysis for Karamoja. Integrated Food Security Phase Classification. Uganda IPC Technical Working Group, 2015.Available online: http://www.ipcinfo.org/fileadmin/user_upload/ipcinfo/docs/RE-

PORT\%20OF\%20THE\%2KARAMOJA\%20IPC_Food\%20Insecurity\%20Analysis_JUNE\%202015.pdf.

[30] New Vision. No Food, no School Pupils in Karamoja. New Vision Daily Newspaper, August 23, 2017, 200716.

[31] T. Neethling. The Security-Development Nexus and the Imperative of Peacebuilding with special reference to the African Context", African Journal on conflict Resolution, 2005 33-60. Available online: https://www.ajol.info/index.php/ajcr/article/view/39385.

[32] ICISS. The Responsibility to Protect. Report of the International Commission on International and State Sovereignty, 2001.Available online:http://responsibilitytoprotect.org/ICISS\%20Report.pdf. 